Received on August 31, 2016. Accepted on May 17, 2017.

${ }^{*}$ Corresponding author: María de los Ángeles Flores, e-mail: mdelosangelesflores@utep.edu

\section{Digital Inequality on the us-Mexico Border: A Multigenerational Case Study in Laredo, Texas}

\author{
Brecha digital en la frontera de EE. UU.-México: Un \\ estudio de caso multigeneracional en Laredo, Texas
}

\author{
María de los Ángeles Flores a* (iD) https://orcid.org/0000-0002-0081-0180 \\ Viviana Rojas ${ }^{b}$ (i) https://orcid.org/0000-0002-8571-0073 \\ Joseph Straubhaar ${ }^{\circ}$ iDttps://orcid.org/0000-0001-8285-1498 \\ ${ }^{a}$ University of Texas at El Paso, Texas, United States of America, e-mail: mdelosangelesflores@utep.edu \\ ${ }^{\text {b } U n i v e r s i t y ~ o f ~ T e x a s ~ a t ~ S a n ~ A n t o n i o, ~ T e x a s, ~ U n i t e d ~ S t a t e s ~ o f ~ A m e r i c a, ~ e-m a i l: ~ v i v i a n a . r o j a s @ u t s a . e d u ~}$ \\ ${ }^{c}$ University of Texas at Austin, Texas, United States of America, e-mail: jdstraubhaar@mail.utexas.edu
}

\section{Abstract}

The purpose of the present study is to determine the cultural and social barriers that are preventing Laredoans from accessing the digital world. This multigenerational study examines how three generations within 16 families relate culturally and socially to technology. Three members from the same family were invited to voluntarily participate in the study, with a total of 48 in-depth, face-to-face interviews being conducted. The present study identified several barriers such as low educational level, low income, lack of English language proficiency, lack of relevant content available in other languages besides English, preference to communicate face-to-face, fear of violence, and endless working hours. Laredo is the least connected city in the nation with $40.2 \%$ non-connectivity rate. Research is needed to understand this digital inequity situation in this borderland city. The theoretical framework used is rooted on Straubhaar's concepts of techno-field, techno-disposition, and techno-capital.

Keywords: digital divide, Laredo Texas, us-Mexico border, multigenerational study.

\section{Resumen}

El objetivo del presente estudio es determinar las barreras culturales y sociales que están impidiendo a los habitantes de Laredo el acceso al mundo digital. Este estudio multigeneracional examina cómo tres generaciones de 16 familias se relacionan culturalmente y socialmente con la tecnología. Tres miembros de la misma familia
This work is licensed under a Creative Commons Attribution-NonCommercial 4.0 International License.
CITATION: Flores, M. de los A., Rojas, V. \& Straubhaar, J. (2017). Digital Inequality on the us-Mexico Border: A Multigenerational Case Study in Laredo, Texas [Brecha digital en la frontera de EE.UU.-México: Un estudio de caso multigeneracional en Laredo, Texas]. Estudios Fronterizos, 18(37), 18-40, doi: 10.21670/ref.2017.37.a02 
fueron invitados a participar voluntariamente en este estudio sumando un total de 48 entrevistas en profundidad. En este estudio se identificaron varias barreras tales como la escasa educación, ingresos económicos limitados, insuficiencia en el dominio del idioma inglés, escasez de contenidos relevantes en otro idioma que no sea inglés, preferencia por la comunicación en persona (cara a cara), miedo a la violencia, y horarios de trabajo interminables. Laredo, con $40.2 \%$ de brecha digital, es la ciudad con menor conectividad digital en la nación. Es necesario desarrollar proyectos de investigación para entender la desconexión digital en esta ciudad fronteriza. La teoría utilizada en este estudio está basada en los conceptos de tecno-campo, tecno-disposición y tecno-capital desarrollados por Straubhaar y su equipo de investigación.

Palabras clave: brecha digital, Laredo Texas, Frontera EE. UU.-México, estudio multigeneracional.

\section{Introduction}

Journalist Jon Brodkin (2014) of the magazine Ars Technica recently published a story regarding the digital divide in America. In the narrative, he listed the top ten cities in the country with low digital connectivity. At the top of that list, holding the first place, as the least connected city in America, was the us-Mexico border city of Laredo, Texas. The source on the list is a study conducted by Bill Callahan, Director of Connect Your Community 2.0, who stated that Laredo has $40.2 \%$ of households lacking internet access at home. He assembled his list using 2013 census data which documented that in Laredo out of the 65685 households, 26376 are not connected to the digital world (United States Census Bureau, 2013).

This low percentage of internet connectivity at home indicated that further research is needed to understand this digital disparity in the borderlands. The purpose of this study is to document the cultural and social barriers that are preventing Laredoans from accessing the digital world. In order to obtain a well-rounded sense of the situation, authors decided to distinguish those walls across generations to understand in great detail the technological dynamics between each age group. This multigenerational approach focus on identifying the cultural and social barriers that are preventing the senior, middle age, and young generations from accessing computers as well as home internet service, hoping to create a bridge to close the gap between non-digital citizens and digital citizens. This investigation assesses the technological involvement of 48 family members of different generations in order to recognize their digital connectivity preferences as well as to determine the barriers that each generation is experiencing.

The relationship between individuals and technology is multifaceted. Therefore, it should be evaluated from different perspectives in order to fully understand this dynamic. The theoretical framework used in this study is Straubhaar, Tufekci, Spence \& Rojas's (2012) concepts of techno-field (relates to the infrastructure that provides access to internet connectivity and access to the digital devices that connect to the internet such as the computer), techno-disposition (relates to the individual's positive, neutral, or negative attitudes toward technology), and techno-capital (relates to the technological knowledge that individuals possess to confidently operate digital devices). The present investigation examines the interplay between techno-field, techno-disposition, and techno-capital among residents of Laredo to serve as a case-study sample of how different generations access, perceive, and operate digital technology. 
Typically, digital divide studies have documented the level of internet connectivity or lack of connectivity (Davison \& Cotten, 2010; Goswami, 2008; Jackson, Fitzgerald, Eye, Zhao, \& Witt, 2010; Strover, 2001; Dijk, 2006; Warf, 2010; Warschauer, 2004; Weinstein \& Clower, 1994; Wirth, 2006) and access to a computer on a particular population or city (Dijk, 2005; DiMaggio, Hargittai, Coral, \& Shafer, 2004; Hacker \& Steiner, 2002; La Pastina \& Quick, 2004; Malecki, 2003; Mertens \& D'Haenens, 2010; Pedrozo, 2013). However, this research analyzes the digital divide question from a different perspective: the social and cultural approach of different generations within the same family focusing on how they interact with technology. Dijk (2005) observes, the physical access to a computer is increasing and at the same time the internet connectivity gap is getting smaller among the population that there is a new type of barrier related to technology use. That is, there is now a line dividing those individuals who do know how to integrate technology for their own benefit and those persons who do not know how to gain benefits from using technology. In short, this innovative split must be examined in order to understand the phenomenon. One solution to this new problematic could be to assess the social and cultural aspects of technological practices.

In addition, Lentz (2000) argues that technology connectivity is only one aspect of the digital divide problematic. She believes that the digital disparity is a direct consequence of each individual's personal history, such as family trajectory, schooling, work opportunities, and geographic location. To Lentz, daily life circumstances play an important role in determining whether or not those individuals are motivated to use digital technologies. The present investigation continues Dijk (2005) and Lentz views but looking a different population.

This study focuses on identifying the type of technological culture that border families have toward the use of digital equipment such as computers, cell phones, iPods, iPads, internet, e-mail, and search engines, among others, to determine what are the favorite technological devices as well as internet services that Laredo families prefer to use in their daily activities. Each city in America has developed its own and unique town culture that embraces or rejects technology. This paper will recognize the culture of technology in Laredo concentrating on the types of positive and negative conditions that are generating the digital divide situation in this city.

\section{Literature Review}

The relationship between people and technology is dynamic and complex. This investigation focuses on the examination of the interplay between digital technology and the Texas border society. The present study examines the digital inequality through the lens of Pierre Bourdieu's concepts of field, habitus, and capital (Bourdieu, 1980). All three concepts depend on each other and they are in constant interaction with each other. The presence of all three interrelated concepts is essential in order to understand the social transformation. Bourdieu used those concepts to understand, measure, and document social transformation. It is worth explaining each one of those concepts further. Bourdieu defines field as the context situation surrounding the interplay dynamics among the different forms of capital (Bourdieu, 1980). In a particular field, people operate as social agents interchanging diverse practices in order to maintain, increase, or decrease capital. Individuals, through the course of their lives, interact in a variety of fields displaying the 
different types of capital that they have accumulated through the years such as education, economic resources, and social connections (Bourdieu, 1980). The next concept, habitus, is expressed as a set of rules of action and objectives to achieve within a particular field (Bourdieu, 1980). Those rules of action generate similar practices among members of the same group at the individual and community levels (Bourdieu, 1993).

The last concept is capital. Bourdieu describes that each individual possesses three types of capital: economic, cultural, and social among other forms of capital. Economic capital is the ability to accumulate monetary means and the level of accessibility to money (Bourdieu, 1985). Cultural capital means knowledge acquired through the years from family traditions and schooling, which shape individuals' inclinations to consume a particular set of cultural products (Bourdieu, 1985). Social capital is a system of social relations that, over time, develop into social resources that individuals could use to reaffirm their class identity, expand their work relations, and socialize, permitting the expansion of their cultural as well as their economic capital (Bourdieu, 1985). From Bourdieu's perspective, cultural capital can be transformed into economic capital, and social capital can be transformed into cultural and economic capital (Bourdieu, 1985). Furthermore, the combination of social capital and cultural capital could potentially lead to social mobility. Recently, Straubhaar et al. (2012) used Bourdieu's concepts of field, habitus, and capital to explain the social and cultural dimension of the digital divide in Texas, specifically in Austin. The state capital is also known as a "technopolis", meaning "a city whose economy focuses on recent technological developments and industries" (Straubhaar et al., 2012, p. 2). The city leaders' major emphasis on technology could eventually leave some groups of the population out of this innovative economic system due to a lack of access to technology (not having access to a computer and the internet) or for lacking motivation to incorporate those digital tools into their lives.

Based on Bourdieu's work to comprehend individuals' attitudes, perceptions, and knowledge, Straubhaar et al. (2012) developed three concepts: techno-field, technodisposition, and techno-capital to document the digital divide phenomenon. That is, each of Bourdieu's key concepts-field, habitus, and capital-were modified to explain the particular relationship between technology and people. Therefore, each of the new terms begins with the word techno. The careful examination of all three interrelated concepts together provides a comprehensive representation of the relationship between technology and society. Straubhaar et al. (2012) push the envelope forward from the traditional digital divide examination that focuses on the physical access to a computer and the connectivity structures by geographic location to the internet service into the incorporation of the study of cultural and social aspects directly associated with the digital inequity.

Techno-field is used to describe "a site, or structured space, where struggles over media access are enacted by appropriating resources" (Straubhaar et al., 2012, p. 8). Technofield refers to the individual's ability to access and navigate the digital world by having access to the internet service as well as access to a computer, which is the primary digital tool that permits individuals to navigate the internet: "The techno-field is analyzed as an arena where human agency is enacted in relation to other social forces-political, economic, social, cultural, and so forth" (Straubhaar et al., 2012, p. 9). The term technofield further refers to that societal, financial, governmental, and artistic institution that creates a particular context and exercises influence on an individual's life.

Techno-disposition is the concept that Straubhaar et al. (2012) brought into the technological access and awareness discussion. They argue that manifestations of this 
concept can be easily identified in common social practices such as the family's history of technology as well as the individual's personal experience, thus technology focusing on how each family member perceives (positive, neutral, negative) technology. Other techno-disposition indicators that Straubhaar et al. (2012) suggest are education, technology awareness, desire for information, work requirements, geographical location, and community relations. "People's disposition to technologies, or techno-dispositions, interact in a reciprocal and complex relationship with techno-capital ... Both technodisposition and techno-capital operate within a specific techno-field of human endeavor" (Straubhaar et al., 2012, p. 8).

Furthermore, Straubhaar et al. (2012) argue that those individuals who perceive technology in a positive light will be more likely to spend time embracing technology. However, those individuals who hold a negative perception about technology spend limited time and energy on topics regarding technology. They claim that "techno-capital is a product of techno-disposition" (Straubhaar et al., 2012, p. 9). The term techno-capital refers to the level of knowledge that an individual possesses regarding digital equipment. If an individual has low technological capital, that person will not be comfortable using it and incorporating digital devices into their daily routines. However, if a person has high technological capital, that person will be very comfortable using it and all types of digital tools will be part of that individual's everyday life. "Techno-capital is a specific form of cultural capital encompassing the acquired knowledge and skills to use information technologies in ways that are considered personally empowering or useful" (Straubhaar et al., 2012, p. 8). That is, the more knowledge an individual has on how to operate technological tools such as computers, iPods, tablets, and smartphones, among others, the higher the level of empowerment that person will have about using it. In addition, Straubhaar et al. (2012) described social capital as neighborhood interactions, family ties and history, and perceived social mobility, among others. Furthermore, to Straubhaar et al. (2012) economic capital refers to income and occupation, among others.

This innovative intellectual approach to digital inequality research was tested by Rojas et al. (2012) in Austin, Texas. They conducted a longitudinal comparative case study over a 10-year period. The team interviewed 50 individuals of working class minorities, mainly African Americans and Hispanics, who reside in the east sector of the city. According to Rojas, Straubhaar, Fuentes-Bautista \& Piñon (2009), in their first wave of interviews from 1999, the researchers concentrated their efforts on high school minority students as well as their parents. They found that gender, class, and ethnicity played a role in the technodisposition attitudes toward technology. The parents lacked access to media outlets during their youth, but when interviewed, they had cell phones, radio, and television, among other things. Nevertheless, parents reflected a positive attitude towards technology, recognizing its importance in their children's future. In addition, those parents recognized that technology provided their children with access to pornography. According to Rojas et al. (2009), their children were tech savvy, had a wider use of media outlets, and their main use was entertainment. Also, through social capital, teenagers raised their level of interest for computers and the internet. Kids considered computer classes at school to be tedious because its primary focus was on developing keyboarding skills. Teens believed that the internet is an efficient digital instrument for research, shopping, emailing, and watching television programs.

The second wave of interviews was conducted ten years later (2009) with college students. Another generation was included to document a multigenerational approach, allowing digital trends within families to be determined. According to Rojas et al. (2012), 
the results indicated an intense communication between family members using a variety of digital technological tools-cell phone, text, e-mail. Grandparents and parents transmitted their expectation to succeed in life through upward social mobility achieved with education. The study documented an interesting flow of cultural capital from youngest to senior members. Parents (and grandchildren) were purchasing a variety of technological devices for their parents (and grandparents) as well as teaching them how to use them. In addition, Rojas et al. (2012) observed the different use of the same digital device, the cell phone. Grandparents and parents used the cell phone to make-receive calls. However, grandchildren had a broader habit of using their cell phones for multiple functions such as calling, texting, emailing, and photographing, among others. Furthermore, computer use among parents was mainly for work purposes, and for their children, it was school and work related. The main news source for the youngest generation was the internet.

On a separate study, Rojas et al. (2009) interviewed 28 individuals who were workingclass Latino adults living in Austin, Texas, about their interaction with technology. They implemented a multi-method approach, conducting in-depth interviews several times with the same individuals to determine their social, economic, cultural capital. The researchers found that education and English language expertise were the main driving factors in this group. The results indicated that individual's economic and cultural capital marked their incentive to use technology. The outcomes also showed that $50 \%$ of respondents stated owning and using computers and internet at home mostly for communication (e-mail) purposes, to seek information (news), and for entertainment. Furthermore, $11 \%$ of participants indicated that they did not have a computer at home, but used the internet at work, in the public library, and at restaurants that offer Wi-Fi services. In addition, the authors determined two main factors preventing Latinos from accessing the internet: low educational level (incomplete high school or junior high) and religious beliefs. Respondents believed that the internet has the risk of exposing them to pornography.

Regarding the digital divide examination in the us-Mexico borderlands, La Pastina \& Quick (2004) conducted research in south Texas, in the area known as "Rio Grande Valley." This geographic area consists of four counties (Starr, Hidalgo Willacy, and Cameron) from Roma to Brownsville. Qualitative as well as quantitative methodologies were implemented in their study. The researchers collected data from a convenient sample using two instruments: face-to-face interviews in community centers located in Colonias and a survey distributed in community centers, libraries, and workforce offices. The total number of participants was 239 individuals from 18 to 74 years old, the majority with low education level and earning less than $\$ 20 \mathrm{k}$ a year. The outcomes indicated that $54 \%$ of participants used the computer for work purposes, other uses were $27 \%$ leisure, and 20\% to access the internet. Regarding the specific function that the internet provides to border residents, the results determined that their primary purpose is to $37 \%$ search for information, $23 \%$ education, $21 \%$ entertainment, and $20 \%$ communication. In addition, the results documented that residents prefer to communicate face to face over traditional mass media (telephones, magazines, newspaper, and television) and new media (e-mail, internet). Respondents paid more attention to information retrieved from family and friends than from traditional and new media outlets. Nevertheless, television is significant in satisfying their entertainment needs. The respondents were skeptical about information received via e-mail because of fear of receiving viruses and scams.

The present research paper continues the examination of the digital divide on the us/Mexico border by focusing on Laredo. This investigation expands the digital divide 
examination area by incorporating the next largest border city located north of the Rio Grande Valley. The purpose is to determine the social and cultural barriers that are preventing Laredoans from entering the digital world. This paper uses the key concepts of techno-disposition, techno-field, and techno-capital as the intellectual foundation for the analysis. There are three research questions guiding this investigation: (1) How do the $1^{\text {st }}$, $2^{\text {nd }}$, and $3^{\text {rd }}$ generations of Laredo families relate to their own family as well as individual's positive or negative attitudes toward technology in their daily lives? (2) How do the $1^{\text {st }}, 2^{\text {nd }}$, and $3^{\text {rd }}$ generations of Laredo families perceive the importance of technological knowledge that individuals possess to confidently operate digital devices in their daily lives? (3) How do the $1^{\text {st }}, 2^{\text {nd }}$, and $3^{\text {rd }}$ generations of Laredo families relate to the infrastructure that provides access to internet connectivity and access to the digital devices that connect to the internet in their daily lives? The digital barriers identified in previous studies were: preconception of particular gender roles, predetermined ethnicity role perceptions, low educational level, low income, lack of digital literacy, lack of English-language proficiency, lack of content in other language (Spanish), religious beliefs, and preference to communicate face to face. This paper is testing whether or not those barriers are present in Laredo, and if the digital walls in Laredo are different from the ones already identified in other parts of Texas. The methodology section is presented next.

\section{Methodology}

A qualitative methodology was used to gather scientific data concerning the use of digital technology in Laredo. The Texas A\&M International University Institutional Review Board approved this research protocol (\#20120919) as well as the questionnaire used to gather the data. The one-on-one in-depth personal interview was the main instrument used to document the digital inequality. All interviewers received special training on human subjects from the Collaborative Institutional Training Initiative program. In addition, the second author of this paper-trained student-interviewers.

The sample consisted of 16 families that voluntarily consented to participate in this study. There was no monetary compensation for the participants. The interviewer informed each contributor that their conversation was about his/her particular use of several digital tools. Every interviewee gave his or her consent prior to beginning the conversation. In addition, they had the right to withdraw from this study at any point in the conversation. In order to keep their confidentiality, participants were asked to select a pen name. Due to the particular characteristics of our geographical location at the us/ Mexico border and the constant social dynamic with Mexico, some participants could be Mexican citizens living in the us or recent immigrants.

In order to ensure representation from the entire community, families who reside in each of the eight City of Laredo council districts were invited to participate. Laredo's Council District Boundaries map created by the Office of Geographic Information Systems was used as the reference point to delimit each council sector. When this study was conducted, the Mayor was Raúl González Salinas and the City Council members were Mike Garza (District 1), Esteban Rangel (District 2), Alejandro Perez, Jr. (District 3), Juan Narvaez (District 4), Roque Vela (District 5), Charlie San Miguel (District 6), Jorge Vera (District 7), and Cindy Liendo (District 8). The home address of the senior member of 
each family was used to determine the entire family's district representation, two families represented each district.

The purpose of this study is to determine the cultural and social barriers that are preventing Laredoans from becoming digital citizens. In order to document the technological dynamics in great detail authors decided to follow a multigenerational approach where three generations of the same family were invited to participate.

Authors identified the "third generation" as all individuals over the age of 18 but under 35 (young). The "second generation" was designated from 36 to 55 (middle age), and the "first generation" from 56 and above (senior). In this case, this multigenerational technique was applied in Laredo to determine the technological adaptation process of 48 residents ( $44 \%$ female, $56 \%$ male) who participated in this study.

The questionnaire used was an adaptation from the original instrument developed in 1999 by Rojas, Straubhaar, Spence, Roychowdhury, Okur, Piñon, and FuentesBautista. The questionnaire deployed in Laredo took about 30 minutes per participant, and consisted of five sections. The first section was the "Consent Form" where participants were informed about the purpose of the study, confidentiality protocol, and voluntary participation. This section ended by asking participants if she/he would like to take part in this study. If the response was positive, the interviewer continued with the remaining four sections. However, if the answer was negative, the interviewer would thank the person and stop the interview at that moment. The second section, "Demographic Information", generated overall data about the subjects' demographic characteristics such as age, race, gender, education, and years of residency in the city, among other things.

The third section, Techno-Capital, inquired about the knowledge that each participant had about technology. For example, questions regarding computer operation, software, search engines, e-mail use, etc. The fourth section, Techno-Field, focused on the type of connectivity access to the digital world that each participant had such as inquiries about the subject's access to the internet, modem, Wi-Fi service, public access, private access, connection speed, etc. The last section, Techno-Disposition, examined the subject's attitudes toward technology innovations focusing on the perception that participants had about the role of technology in their lives. For instance, questions were asked about their perception of the use of computers and the internet at work, at social gatherings, at school, and so on. This innovative border survey was first tested in all three generations of two families. Then, the instrument was applied to gather the data of 16 families. The results are presented in the next section.

\section{Results}

The authors would like to begin the cultural and social barriers discussion by presenting general demographic information about the participants. All of them claimed to be Hispanic, more precisely Mexican-American. Each respondent was classified in a particular group according to their chronological age. Some of the life experiences that participants felt most proud of were to have a united and supportive family, parents still together, being able to raise smart and well-mannered children, pursue a university education, to be a hard-working individual, to be able to acculturate into the American lifestyle. Respondents pointed out that the most important lesson that they have learned from 
their family was to be patient, to love, to work hard, to believe in oneself, to be close to family members, manners, respect, education, and never give up no matter what.

The immigration history of participants is unique to the border lifestyle; several members of each generation were born in America and raised on this side of the border. However, other participants were raised in Nuevo Laredo and crossed the bridge across the Rio Grande River every day to Laredo to attend school or to work. In addition, there are cases where either the mother or the father is a us citizen and they process the immigration documents for their partner in order to be together.

Also, several participants commented on the economic advantages of living on the Mexican side of the border. The money goes a long way, if an individual earns in dollars and spends in pesos, with the exchange rate their quality of life increases on the Mexican side having access to great housing, food, public services, etc. Other respondents remarked to having two homes, one in Laredo and the other in Nuevo Laredo, due to business and family matters. Moreover, some respondents commented that they have moved out from Laredo for a few years to live in Chicago-IL, Memphis-Tn, Los Angeles-CA, McAllen-Tx, San Antonio-Tx, Houston-Tx, and Austin-Tx. Participants commented that when they were growing up they dreamed about becoming a doctor, a nurse, a teacher, a lawyer, a biologist, a police officer, a lab technician, a business owner, a wife, and a mother.

Border residents end up in their current profession because of their family's influence (grandparents-parents-siblings), by discovering their passion about something, and by chance alone. Overall, participants have learned from their families to always work hard and finish school. At the time of the study, $60 \%$ of participants owned a computer and $40 \%$ did not. In addition, $35 \%$ of respondents had no access to internet at home, and $65 \%$ had internet access in the form of broadband service.

\section{Laredoans Attitudes Toward Technology}

The first research question inquired about how the $1^{\text {st }}, 2^{\text {nd }}$, and $3^{\text {rd }}$ generations of Laredo families relate to their own family's as well as individual's positive or negative attitudes toward technology in their daily lives. This section presents the respondents' history of technology use in their families with a particular focus on computer and internet use. The outcomes are presented by generation starting with the senior participants $\left(1^{\text {st }}\right.$ generation) and ending with the youngest contributors ( $3^{\text {rd }}$ generation).

\section{First Generation}

When the $1^{\text {st }}$ generation was growing up, the technologies around their homes were black \& white television, radio, land telephone, and typewriter. Participants mentioned that they did not have much technology around the house due to lack of economic means. The most important notion about technology that senior participants learned from their family was that it gathered the family because it was a collective activity and experience. The first time that senior respondents were in contact with the computer was through their work and family. For example, Julian, 70, worked for the City Health Department. He recalls his first encounter with computers back in the 1980s, "At work, we had computers that 
were more like an electronic typewriter. The only program available for computers was word processing, we mainly used it to create databases to enter and store data." Brenda, 58 , had a similar experience, "After 20 years of being a housewife, I had to return to work. When I left the workforce to get married, we used electric typewriters. Now, companies use computers, so I had to learn, on the fly, how to operate it." Family is another entry point for senior respondents to become familiar with the internet. Sofia, 67, explained, "I went to visit my 3-year-old granddaughter. She was playing on the computer. I could not believe that a baby could play with computers, especially because I did not know how to turn it on!"

In terms of the internet, $7 \%$ of senior respondents had their computer connected to the internet. However, several of them view the internet as a harmful practice because it is intrusive. Jaime, 65, a grandfather of 4 kids said, "Children who have access to the internet can be exposed to all kinds of destructive information that is not appropriated for their age. It has no filters, no morals, no values." Similarly, Blanca, 67, considers that the internet alters kids' schedules, especially at bedtime, "We used to have internet at home, but it kept my grandkids up at night. I would send them to bed. Later, I would check on them and they were in their bed, but they were watching on their iPods who knows what!" Several respondents claimed that the internet is wounding families because it is a private activity, not a shared activity for everybody to enjoy.

\section{Second Generation}

The study outcomes determined that when the second-generation respondents were growing up, they had radio, black \& white TV, color TV, cable television, land telephone, 8 -track cassette system, cassette tapes, long play discs, turntable, CD players, and video games around their house for entertainment and information purposes. The most important thing that second-generation participants learned about technology in their family was that technology is not essential for daily life. As Danny, 38, remembers, "When I was growing up, there was no internet. This type of technology did not exist back then. Consequently, my parents did not influence me on pursuing technology. I met the internet in 97 when I was already married."

The first time that the second-generation had contact with computers was by means of work-related activities. Joe, 43, recalls his first encounter with computers, "Back when I was 17 years old, I started to work in a bank where all the monetary transactions were made on computers, not accounting notebooks with columns." Likewise, Kevin, 41, who works for an environmental protection state agency remembers when his supervisor decided to go paperless, "Our office was among the first ones to conduct all our business paperless, to set the example in the community. Everything had to be done through a computer." Belinda, 39, had a similar experience with the school district where she works as a clerk "the district decided to keep all the student records electronically. I had no choice, if I wanted to keep my job, I had to learn it."

The respondents explained their feelings regarding the internet. Ana, 47, "the internet presents negative connotations because it can help you find information, but also children can have access to derogatory [negative] information." Other respondents commented that the internet has created problems in their marriage, their family, and their personal 
life. Tina, 48, commented, "my husband has an 8 to 5 job, but he is constantly bringing work to do or his boss will send him last-minute work that must be done, constantly reducing his time devoted to our family." Likewise, Andrea, 49, accepted as true that the internet is intrusive in her life "I have an 8 to 5 job, but my boss constantly sends me e-mails after hours that he expects to be answered in less than 10 minutes after he sends it out. It's so frustrating to me."

The authors found unique cultural characteristics that prevent people from accessing the digital world, as Ibrahim, 51, describes the internet is viewed as an outsider, "In Laredo, things operate under the 'patron' system, a few families implicitly rule a whole community. Under these cultural circumstances information means power. Outsiders find that locals keep information to themselves because they know that their survival depends on it." In this case, the internet is a tool to share information, but if locals share that information, they know they would become fragile, weak, putting their survival at risk. Furthermore, Paulina, 52, illuminates in detail how the communication system works in this city, "We like the face-to-face communication because culturally we reinforce a small-town behavior. As a rule, to survive in this town, everybody stays quiet. The internet makes too much noise, everybody knows what you are up to. It's dangerous!" In other words, residents know that eventually word will get out and their job could be in jeopardy.

\section{Third Generation}

The third-generation is the most connected of all generations. During their childhood, they had access to computers, video games (Nintendo, Xbox), radio, color television, cable television, CD players, iPads, iPods, Android-Tablets, kindle devices, and blueray players around their home. The most important message that third-generation respondents learned about technology from their family was that people do not need digital equipment to seek entertainment, intellectual knowledge, or friends; which is contrary to what the younger generation would say given their reliance on technology. The first time that they had access to a computer was through school activities, parents, and work. Belen, 19, remembers her first encounter with computers, "I was in elementary school. We would use laptops that the teacher would lend us to do assignments on it." A few parents played a significant role teaching their children how to use the computer as Ramiro, 24, recalls when his father introduced him to technology, "When I was about 10 years old, my dad got one computer for the family. He started clicking on everything, just to see what happened. Then, he showed me and my sister how to use it." The whole family was learning how to use technology using discovery dispositions thru trial and error method. Also, freelance work led Judith, 25, to discover computers. Her first job was as hostess at birthday parties, "I dress up as a particular Disney princess depending on the birthday girl's favorite character. I would use my computer to play the music for the karaoke version of my show. It was fun!" However, some jobs do not require as much technological knowledge. Melissa, 23, works at a fast food restaurant and commented "I don't use the internet at work. We take orders on touch screens."

Generally, older generations provide guidance and wisdom to the new generations. However, the research outcomes reveal that this is not the tendency in terms of technological knowledge. The youngest generations usually made the oldest generation aware about technological advances, not the other way around. As respondents stated, 
this reverse process has been difficult on them. Aaron, 22, shared his experience with us, "it has been a very frustrating situation for me. My parents do not want me to spend a lot of time on the internet. To them, it is a dangerous place where everybody lies about everything." Also, Benito, 20, has been facing a similar situation "my grandma is always all over me, arguing that my generation does not know how to socialize properly. She complains about young people sitting next to each other without talking to each other."

Some young contributors started to practicing self-censorship because of negative experiences while using the internet. Margaret, 24, mentioned that there is bullying taking place over the internet, "My best friend from high school had a problem with some girls who were making fun of her everyday all over Facebook (Fв). She was devastated. After witnessing all her suffering. I do not use social media anymore." Confusion on how to handle crowds is how David, 27, classifies what is going on in social media, "my generation has a hard time understanding the difference between private and public life. FB is a massive public medium where your information is exposed to many people instantaneously. Therefore, posting private stuff that can harm them." The results indicated that another cause for young people to reject the internet, particularly social media, is the constant feeling of being overwhelmed with information 24/7. Justin, 23, rejects using social media, “I don't have a twitter account because I don't want to get hooked on it. I used to have а ғв page, but I felt overwhelmed with so much information so I decided to quit."

In short, members of the $1^{\text {st }}$ generation believe that computers and internet are intrusive and harmful to their families. Similarity, the $2^{\text {nd }}$ generation considers that technology is useful, but intrusive at the same time. Technology is useful to work-related activities and intrusive because it creates social noise, creates personal problems with significant others, children, parents, and prevents them from having a personal life to enjoy. In contrast, for the $3^{\text {rd }}$ generation technology is useful to do homework. However, this generation stated that it was intrusive because it can be used for negative purposes such as cyber bullying, and promoting low motivation to read, study, or develop criticalthinking skills.

\section{Laredoans Technological Knowledge to Confidently Operate Digital Devices}

The second research question ask about how the $1^{\text {st }}, 2^{\text {nd }}$, and $3^{\text {rd }}$ generations of Laredo families perceive the importance of technological knowledge that individuals possess to confidently operate digital devices in their daily lives. This section describes the participants drive to learn how to manipulate digital gadgets. The outcomes are presented by generation starting with the senior participants ( $1^{\text {st }}$ generation) and ending with the youngest contributors ( $3^{\text {rd }}$ generation).

\section{First Generation}

The first generation keeps in touch with their local family and friends by visiting them at their homes and social gatherings. The outcomes have determined that the first 
choice of participants was to call their friends up using a landline phone. Nevertheless, this communication pattern sometimes does not apply to their family members. Senior participants stated that they had to learn how to use digital technology in order to communicate with their children and grandchildren. For instance, Rosa María, 68, alleged "my kids prefer that I text them. I have a hard time texting because my fingers are too big for the letters of my cell phone, but when I text them they return the text right away."

Outcomes showed that occasionally a negative experience could motivate respondents to integrate technology into their lives, such as Justin, 82, who was waiting for his granddaughter to get out of school remarked, "I received a phone call, while answering, a police officer saw me and gave me a ticket. I went to the Judge, I agreed to take a 30-minute car technology class as payment for my ticket." Moreover, a landline phone call is the main means of communication with their friends and family who are abroad. Ray, 74, commented, "my two sisters live in Mexico. I live here because I fell in love with a beautiful girl from Laredo. I made a deal with my phone company for a fixed rate. I can call all I want to Mexico." In addition, some respondents stated that they use Nextel (a mix of walkie-talkie \& cell phone device) to communicate with their family and friends, especially those living or working in Mexico because the signal can be reached on both sides of the border.

The results demonstrated that a few of the participants communicate via Skype with their family members who live out of town, but always using a local family member to set up the communication. José, 71, describes the communication method, "the most important step in this process is to make sure that my grandson is back from school. He is the only one who knows how to communicate with his mom." Outcomes showed that senior respondents believe that technology involves intellectual effort, a learning curve that sometimes is complex. Dolores, 74, "Access to technology does not mean buying the computer. The real problem comes when you have to use it. Turning it on is easy, but figuring out what each icon does is challenging." The first-generation knows that they can find the information on the internet. However, their grandchildren do the practical performance of this digital operation. Charlie, 72, commented how his grandchildren are his techno-teachers, "all the computer controls were in English, my grandchildren reprogramed my computer switching it to Spanish. If I want to find something on the internet, they assist me in finding the information because I spell the word for them to type it." Likewise, Reyna, 69, reaches out to her kids for a helping hand "when I need information, I ask my grandson to look it up for me. I prefer my internet on the cell because I can look up information anywhere. At home, I do not have internet because I do not use it."

The results indicated that the main software that the first-generation used on the computer was Microsoft Office, focusing on Word, Excel, and Outlook. The leading task that senior respondents performed when accessing the digital world was social media, more specifically FB, followed by YouTube videos, and search engines. Seniors use the internet to look up information, to connect with people, and for entertainment. In addition, outcomes indicated that $14 \%$ of senior respondents used email, and that $86 \%$ of them do not have an email account. Results showed that when seniors seek information, $50 \%$ of them turn to traditional media, $22 \%$ consult their grandchildren, $20 \%$ ask their children, and $8 \%$ consult the internet. 


\section{Second Generation}

The second generation keeps in touch with their local family and friends by texting them. Participants indicated that they prefer to text, the second choice is making a call to their cell phones, and the last resource is to communicate via email and social media. Irma, 48, explained, "When I need to ask my friends and family a quick question, in order to not disturb any party and not make noises, I send them a text. They answer right away because it's private and discreet!" Furthermore, Sonia, 42, firmly believes that social media, particularly $\mathrm{FB}$, is the best way to communicate with her children, "My son has his FB open on his phone all the time. If I text him or call him I can wait several hours for his response, but if I send him a private message on $\mathrm{FB}$ he responds in minutes." This same pattern was observed to be employed to communicate with out-oftown family and friends. Baltazar, 39, likes to communicate with his mother and sister who live in San Antonio via texting, "my mom is always very busy at work. I like to text her to not interfere with her work duties or her driving. My sister is a homemaker, but keeps a very strict schedule for my niece and nephew, so I do not like to interrupt or call in a bad time. I think texting is a very effective way to communicate with people." Participants commented that they own two phones, a cell phone with a us number and a standard phone (no internet capabilities) pay-as-you-go type with a Mexican number to be able to receive calls from both sides of the border. In terms of the internet, second-generation respondents declared that when they need to seek information, $50 \%$ of them go to the internet, $34 \%$ consult the traditional media, $16 \%$ ask their friends and/or their spouses.

Responses indicated that $57 \%$ do not know how to use search engines, but $43 \%$ do. Members of the second generation indicated that $32 \%$ of them use social media such as FB / Pandora/Instagram as their main computer software, followed by $23 \%$ search engines, $17 \%$ Microsoft Office, 9\% Skype, and 5\% Messenger. The other 14\% do not know how to use computer software. At work, respondents use fax machines, desktop computers, laptops, copier machines, and scanners. Several second-generation respondents believe that their children have become their teachers. Carol, 47, stated that without her daughter's assistance she would not be able to learn digital gadgets, "she teaches me a lot of stuff that I don't know. My life has changed so much that I depend a lot on technology and cannot live or work without it." Likewise, Vanessa, 39, remarked that her parents teach her how to use the technology of their time such as 8-track cartridges, turntable, and so forth, "Nowadays, technology is changing so fast that we must learn it from our children. In terms of technology, the cycle of transfer of knowledge takes place from the young to the old, not the other way around." The results determined that for the second-generation, work requirements prepare respondents to keep up with technology. Victor, 43, mentioned, "My work keeps me up to date with technology. I work for an international trade company. We are in charge of creating all the paperwork needed to import and export goods. Customs change their procedures all the time and we need to be on top of the game. Procedures have changed tremendously over the years, now all the paperwork is electronic. Nowadays, all that is needed at the international bridge is a code. Those numbers provide all the information required to the Customs officer conducting the valuation on the merchandise." 


\section{Third Generation}

Facebook is the favorite venue of communication for the third-generation to stay in touch with their local and out-of-town friends. Kimberly, 20, explained how she uses this social media outlet, "it's easier to contact my friends thorough FB than through email or phone. Everybody checks their FB 24/7. Everybody is available all the time." Results showed that in terms of family who live in town, calling and texting are the options to communicate with loved ones. Linda, 22, explains how she communicates with her grandfather, "He likes me to call him. In case it is not possible, he has agreed to read my texts. I would like to emphasize on 'read' because he does not know how to answer my texts." Sometimes family cultural traditions can be an obstacle to using technology. María, 20, grew up under strict social rules, "my mother always told me that it was disrespectful not to make eye contact with the other person when you were talking to them. Therefore, only face-to-face communication is allowed." Skype was a popular option to communicate with out-of-town family.

José, 19, communicates with his grandmother once a week "I used to make an international call to my grandma, but she got a computer recently, so now we Skype. It was not an easy transition for her. I had to train my grandma, but it was worth it. Overall, we are both saving a lot of money". When members of the third-generation need information, they go to the internet as their first preference. Then, they consult traditional media outlets and seek assistance with their friends. The top computer program that this generation uses for work/school/social is social media with $41 \%$, followed by search engines with 23\%, Skype with 20\%, and Microsoft Office with $16 \%$.

During the 2012 presidential election, their main source for news was the internet, YouTube, Facebook, and Twitter. In addition, respondents made the clarification that they watch only the presidential debates on television. When members of the third-generation need information, they go to the internet as their first choice for preference. Then, they consult traditional media outlets (newspapers \& radio) and seek assistance with their friends. Moreover, the top computer program that this generation uses for work/school/ social is social media (Facebook, Twitter, Instagram, YouTube) with $41 \%$, followed by Internet Explorer with 23\%, Skype with 20\%, and Microsoft Office (Word, PowerPoint, Excel, Outlook) with $16 \%$. In addition, respondents commented that at work they use several technological devices such as smart cell phones, computers, internet, social media, and copier machine.

In summary, the $1^{\text {st }}$ generation likes to call and visit their local friends, but for the family they had to learn technology in order to communicate with them. Negative experiences have also motivated them to learn the technology. For the out-of-town friends and family, they mainly call; a very limited number of participants use Skype to communicate with family. Senior members believe that technology is complex and involves a learning process. Therefore, their grandchildren have become their hands-on person and their teachers. The $2^{\text {nd }}$ generation uses texting to keep in touch with local friends and family. They consider that texting is private, quiet, and non-disturbing; work is the main driving force for this generation to stay on top of the technological game, constantly learning new software. Finally, the $3^{\text {rd }}$ generation uses FB to stay in touch with their local and out-of-town friends. Nevertheless, to communicate with local family they use calling and texting. For communicating with family abroad, they use Skype. The internet is their main source of information. 


\section{Laredoans Access to Internet Connectivity and Digital Devices}

Finally, the third research question enquire about how the $1^{\text {st }}, 2^{\text {nd }}$, and $3^{\text {rd }}$ generations of Laredo families relate to the infrastructure that provides access to internet connectivity and access to the digital devices that connect to the internet in their daily lives. This section illustrates what type of infrastructure people have access to internet connectivity as well as computers. The outcomes are presented by generation starting with the senior participants and ending with the youngest contributors.

\section{First Generation}

First-generation participants recalled that when they were introduced to the internet, the connection was dial up. As Clarisse, 65, described, "During weekdays, I take care of my two grandkids after school. They do their homework at my house, but they need internet access to do homework, so I contracted the service. However, I have very little use of it myself." Results demonstrated that some seniors had to update to broadband because their grandchildren could not stand how slow their internet service was. Jimmy, 68 , shared with us, "I am a grandfather of 5 children. They all suggested that I upgrade my service because my internet was too slow and when all of them are visiting, they could not get on the internet to play games." The authors observed that the majority of interviewees, who claim to have access to the internet, use their cell phone to access the internet, not the computer. Homero, 69, stated, "I access the internet via cell phone, because it's more convenient for me. The access is easier to remember than on the computer. On the cell phone, it is only one-step; on the computer, it's a complicated task because it requires several steps."

Some of the respondents are becoming adventurers by operating a smart cell phone, usually obtained as gifts. As Susana, 74, explains, "I got an iPhone for Christmas from my son and promised him that I would learn to use it. I just click on this compass icon and go into whatever I want to look for." Other participants commented on the advantages of having applications downloaded into their smart cell phones, as Edmundo, 69, clarified, "I use the GPS app that locates in the golf course the distances, so it tells you how far are you in the green." Brianna, 64, shared with us her story about the GPS app that saved her expedition to Houston "We went to visit our grandchildren, before we knew it, we were lost in the city. Then, I remembered that my grandson told me that I have a GPS app on my iPhone. I was so lucky to remember how to use it." Several respondents pointed out their rationale on the economics behind the internet connection. George, 71, "I am already retired, so I have to be very careful with my money. My wife and I decided to have internet on the smart cell phone. We used to have it at home too, but it was too expensive for us."

\section{Second Generation}

The second-generation uses the computer and the internet to work, conduct research, pay bills, socialize, and for entertainment purposes. However, the computer is not always their first choice. There were respondents who use other digital devices to access the 
internet. Alfonso, 52, stated, "I like to access the internet on my tablet and on my phone because they are more convenient than a computer." Xavier, 47, commented on a similar situation, "I was out to lunch. Then, I received a phone call from my boss who needed some information ASAP. I used my tablet as a hot spot to my personal laptop; I connected to my office computer to do some work." Other respondents use it for personal banking purposes. Sarah, 48, specified, "Once a month, I access my bank account and program all my bill payments. Before, when I needed to pay my bills, I had to make the checks, buy stamps, and mail them out, not anymore!" Language is another variable in the digital divide gap in this border town as Pablo, 45, comments, "I can read Spanish better than English, so I prefer to search for websites in Spanish." Others prefer to access the internet via cell phone, as Suleiman, 47, shares "computers are beyond my understanding, I use my cell, it's easier. I do not know much English. I can just understand the basics, but I cannot write it. I don't need the computer for work and my cell is all in Spanish." Some participants expressed their economic concern regarding the cost of the internet. Pat, 43, "we don't have internet at home. When my son has to do homework, I let him use my cell phone to connect to the internet. It is cheaper for us and I can supervise the information he is exposing himself to."

\section{Third Generation}

Results determined that the third-generation respondents are the most connected to the internet. For young participants, the internet is viewed as an electronic encyclopedia, which holds the answers to all academic questions, so there is no longer a need for criticalthinking skills. Karen, 19, believes that there is no longer a need to read, "my mom would tell me that I need to read more books to get information, I just get it off the internet. We don't have to read because we have the computers to do the work." Unfortunately, not all the information available on the internet is correct or can be trusted. However, teenage respondents do not have a problem with that because they are making an effort to resolve more complex issues. Sanjuanita, 18, explained how difficult it has been for her to do homework, "my parents don't' speak English, so I really can't turn to them for assistance. So, I turn to the internet to look it up." This young generation has integrated several digital gadgets and the use of the internet to make their life effortless. David, 26, explained, "I use my phone as an alarm, I use it for entertainment purposes while getting ready for work, and I put Pandora on my phone on my way to work."

In summary, the connectivity that the $1^{\text {st }}$ generation has to the internet is mostly via cell phone. They prefer it over connecting through the computer, arguing that connecting via computer is a more complicated task. Senior participants point out that internet cost is an issue to them because each connection has an average cost of $\$ 30.00$, so they don't like to pay twice for the same service. However, some of them have to pay twice because they take care of the grandkids who need the service to do homework. Likewise, members of the $2^{\text {nd }}$ generation like to connect via their cell phone or tablet rather than the computer. To them, the computer connection is more associated with work-related tasks, not with private life. This generation shares the same economic view as the $1^{\text {st }}$ generation. Finally, the $3^{\text {rd }}$ generation is the most connected of all three. They like to access the internet via their computer, their cell phone, their iPad. Sometimes all at the same time because they like to multitask. That is, they use each device to perform a different task. Young participants view the internet as a databank that holds all the answers. 


\section{Discussion}

Laredoans attitudes toward technology found in this study were that the $1^{\text {st }}$ generation believes that technology is not a family activity, but an individual, isolated activity. Seniors had to learn technology under pressure circumstances mainly to stay in touch with family members who refuse to communicate via landline phone. This group views the internet as intrusive because it exposes their family to destructive information and disturbs their grandchildren's bedtime schedule.

The $2^{\text {nd }}$ generation finds technology hazardous because they lose control over what their children are doing on the internet. It is difficult to monitor their children's activities, particularly when they have more intellectual capital than their parents do. This generation commented that Laredo has a particular cultural characteristic that consists of being quiet and calm, everyone keeping to themselves. The internet makes too much "noise", it makes people nervous because everybody knows what you are up to. This cultural aspect can be understood through the local contemporary history. There have been several people killed or jailed on both sides of the border because of the information that they posted on the internet, predominantly social media. Finally, two major barriers were identified in the $3^{\text {rd }}$ generation. Young people frequently feel overwhelmed with information they receive $24 / 7$. This group circumvents the internet to avoid cyber bullying situations.

Laredoans technological knowledge to confidently operate digital devices documented in this study indicated that the $1^{\text {st }}$ generation is under the impression that technology involves an intensive intellectual effort because devices are complex. This group knows what the internet can do, but they are not self-reliant. They rely on a younger person to do the practical task. Some of them had to learn technology through negative experiences. The $2^{\text {nd }}$ generation considers that the internet creates marriage, family, and personal-life problems because working hours never end. This group argues that working schedules have expanded. There is no difference between working hours and personal time, since all of it is work. The $3^{\text {rd }}$ generation faces family cultural traditions that serve as an obstacle to the use of technology. Tradition dictates that face-to-face communication is preferred over digital messaging.

In terms of access to internet connectivity and digital devices, the present study found that Laredoans in the $1^{\text {st }}$ generation indicated that they prefer to connect to the internet via cell phone, not home connection. If they happen to have home internet connection, it is mainly because their grandchildren asked for it. Likewise, the $2^{\text {nd }}$ generation does not prefer to connect to the internet using the computer. They prefer other devices such as cell phone and tablets. Both of these groups identify language and economic resources as barriers to accessing the internet. Those groups argue that there is no need to pay twice for the same service. They prefer to pay for the internet service only on their cell phones. Finally, the $3^{\text {rd }}$ generation is the most connected group. They like to connect several digital devices at the same time in order to multi-task. They want to have access to the internet at home and on their gadgets. This group has no concern about the money issue because their parents pay for their home connection and sometimes even for their cell phones. 


\section{Conclusion}

This multigenerational study documented that the people from Laredo, Texas prefers mobile internet connectivity via their smart cell phones, tablets, and hotspots over a stationary internet connection such as home or office. Consequently, the home connectivity measurement conducted by the Census in 2013 (United States Census Bureau, 2013) indicating that in Laredo out of the 65685 households, 26376 are not connected to the digital world only provides a partial picture of how Laredoans connect to the digital world. According to Bill Callahan, Director of Connect your Community 2.0, the border town of Laredo is considered the least connected city in the nation with $40.2 \%$ of households lacking internet access. This low figure of internet connectivity at home indicated that research should be conducted in Laredo to further understand this digital disparity. This investigation provides evidence that strongly suggests expanding the digital divide connectivity scope to include not just home internet but mobile internet as well in order to measure the level of internet connectivity that a particular city possess. A future study should examine the cell phone connectivity in Laredo.

The type of economic activities and the binational life style, which is typical in Laredo, dictate a particular preference for mobile internet connection. For example, one of the major employers in the city are the international commerce business who are in charge of importing as well as exporting goods in and out of the country. The nature of this particular job is for their employees to be on the international bridge monitoring the merchandize as it is inspected by customs. This federal governmental agency requires that all the paperwork is submitted in digital form self-contained in a code that the driver of the 18-wheeler truck has to provide to customs officers. Typically, workers of those international commerce companies have to update-change information on the spot at the bridge. Subsequently, they choose mobile internet connectivity to be able to conduct those tasks on real time from any location on both sides (us/Mexico) of the international bridge.

This aim of the present investigation is to document the cultural and social barriers that are preventing the people from Laredo to enter the digital world. In order to deeply understand the technological dynamics of this border town, authors decided to take a multigenerational approach determining how three generations of 16 families interrelate with technology focusing on the connectivity infrastructure that is available, their preference in the use of digital devices that connect to the internet, individual's positive and negative attitudes to technology, and the technological knowledge that each individual possess to confidently operate a digital gadget. This study used qualitative methodology to conduct its data collection through 48 in-depth interviews to individuals over 18 years old. At the time of the present study, $60 \%$ of participants owned a home computer and $40 \%$ did not. In addition, $35 \%$ of respondents had no access to internet at home while $65 \%$ of participants had mobile internet access.

The first research question inquired how the $1^{\text {st }}, 2^{\text {nd }}$, and $3^{\text {rd }}$ generations of Laredo families relate to their own families and individual's positive or negative attitudes toward technology in their daily lives. This investigation recognizes that among Laredoans there are more negative attitudes than positive. The negative attitudes of Laredoans were (1) technology interaction is an isolated activity, (2) technology is intrusive because exposes people (particularly children) to destructive information and disturbs their schedule, (3) technology is risky because it's difficult for parents to monitor what their children are 
doing on the internet, (4) technology is too noise making people anxious because there have been people jailed or killed due to the information that they posted on the internet predominantly social media, (5) technology makes young people feel overwhelmed with the constant-nonstop incoming information they receive day and night, and (6) some young adults evade interactions with internet especially social media to avoid cyber bullying situations.

The second research question enquire how the $1^{\text {st }}, 2^{\text {nd }}$, and $3^{\text {rd }}$ generations of Laredo families perceive the importance of technological knowledge that individuals possess to confidently operate digital devices in their daily lives. This study identifies that Laredoans are under the impression that technology (1) requires an intensive intellectual effort because digital machines are complicated to operate, (2) some of them are aware of the internet capabilities, but relay on a young family member to do the hands-on work for them, (3) others were force to learn technology as a direct consequence of a negative experience with the law or under pressure circumstances mainly to say in touch with family members. The majority of respondents indicated that they learn technology at work mainly to be up to date with their work's technological demands.

Lastly, the third research question asked how the $1^{\text {st }}, 2^{\text {nd }}$, and $3^{\text {rd }}$ generations of Laredo families relate to the infrastructure that provides access to internet connectivity and access to the digital devices that connect to the internet in their daily lives. This examination specifies that Laredoans have strong preference to use mobile internet connectivity particularly thru smart cell phones and tablets. They believe that there is no need to pay twice (home and cell phone) for the same internet service. However, young adults like to connect several digital devices at the same time. They like to have internet access at home and on their mobile gadgets usually because they don't have to pay for it.

Overall, this investigation expands the body of knowledge of Straubhaar et al. (2012) concepts of techno-disposition, techno-capital, and techno-field by implementing a multigenerational method of data collection and conducting research in a borderland community. In addition, this study expands the body of knowledge by providing strong evidence that suggest that study of digital connectivity should be expanded to integrate mobile internet services to determine the level of connectivity in a particular population. In terms of digital barriers which prevent people from accessing the digital world, previous investigations identified several social and cultural obstacles such as perception of gender roles and ethic roles, low education level, low income, lack of English-language proficiency, lack of relevant content available in other languages besides English, religious beliefs and preference to communicate face to face. However, the present study documents two additional problems: Fear of violence and endless working hours. Also, this investigation contributes to the digital divide field by analyzing a new location on the us/Mexico border, Laredo. Previous studies documented this digital divide approach in the cities of Austin and the Rio Grande Valley regions of Texas, but this paper analyzes an additional borderland community.

\section{Acknowledgements}

The authors would like to express her gratitude to Dr. Juan Homero Hinojosa (Texas A\&M International University) and Adolfo Mora (UT-Austin) for their comments and suggestions on earlier drafts of this research. Special thanks to the research assistants 
Joanna Amaya, Linda Bravo, Alfredo García, Ashly García, Laura García, Stephanie McCanlas, José Sanchez, Joanna Santillana, and Julio Obscura, all of them communication undergraduate students at Texas A\&M International University. Also, the authors would like to thank each one of the 48 Laredo residents who supported this study by agreeing to participate.

\section{References}

Bourdieu, P. (1980). The Logic of Practice. California, United States of America: Standford University Press.

Bourdieu, P. (1985). The Forms of Capital. In J. Richardson (Ed.), Handbook of Theory and Research for the Sociology of Education (pp. 241-258). New York, United States of America: Greenwood Press.

Bourdieu, P. (1993). The Field of Cultural Production. New York, United States of America: Columbia University Press.

Brodkin, J. (November 4, 2014). In Detroit and other cities, nearly 40 percent go without Internet: Many people can't afford internet service and even lack mobile broadband. Ars Technica, 1. Retrieved from http://arstechnica.com/business/2014/11/ in-detroit-and-other-cities-nearly-40-percent-go-internet-free/

Davison, E. L. \& Cotten, S. R. (2010). Connection Disparities: The Importance of Broadband Connections in Understanding Today's Digital Divide. In E. Ferro, Y. Kumar Dwivedi, J. R. Gil-Garcia, \& M. D. Williams (Eds.), Handbook of Research on Overcoming Digital Divides: Constructing and Equitable and Competitive Information Society (Vol. 1, pp. 346-358). Pennsylvania, United States of America: Information Science Reference.

Dijk, J. van (2005). The Deepening Divide Inequality in the Information Society. California, United States: Sage Publications.

Dijk, J. A. G. M. van (2006). Digital Divide Research, Achievements and Shortcomings. Poetics, 34(4), 221-235. doi: 10.1016/j.poetic.2006.05.004

DiMaggio, P., Hargittai, E., Coral, C. \& Shafer, S. (2004). From Unequal Access to Differentiated Use: A Literature Review and Agenda for Research on Digital Inequality. In K. M. Neckerman (Ed.), Social Inequality (pp. 355-400). New York, United States of America: Russell Sage Foundation.

Goswami, D. (2008). Chapter 6: Wi-Fi: The Network Fix. In R. Sramajiva \& A. Zainudeen (Eds.), ICT Infrastructure in Emergin Asia. Policy and Regulatory Roadblocks (pp. 131156). Canada: International Development Research Centre.

Hacker, K. L. \& Steiner, R. (2002). The Digital Divide for Hispanic Americans. The Howard Journal of Communications, 13(4), 267-283.

Jackson, L. A., Fitzgerald, H. E., Eye, A. V., Zhao, Y. \& Witt, E. A. (2010). The Digital Divides in the U.S.: Access, Broadband, and Nature of Internet Use. In E. Ferro, Y. Kumar Dwivedi, J. R. Gil-Garcia \& M. D. Williams (Eds.), Handbook of Research on Overcoming Digital Divides: Constructing an Equitable and Competitive Information Society (Vol. 1, pp. 223-238). Pennsylvania, United States of America: Information Science Reference. 
La Pastina, A., \& Quick, B. (2004). An Exploration of Internet and Traditional Media Uses in the Rio Grande Valley. Paper presented at the International Communication Association, New Orleans, Louisiana, United States of America.

Lentz, R. (2000). E-Volution of the Digital Divide in the U.s.: A Mayhem of Competing Metrics. Info, 2(4), 355-377.

Malecki, E. (2003). Digital Development in rural areas: Potentials and Pitfalls. Journal of Rural Studies, 19(2), 201-214.

Mertens, S. \& D'Haenens, L. (2010). The Digital Divide Among Young People in Brussels: Social and Cultural Influences on Ownership and Use of Digital Technologies. Communications: The European Journal of Communication Research, 35(2), 187-207. doi:10.1515/ COMM.2010.010

Pedrozo, S. (2013). New Media Use in Brazil: Digital Inclusion or Digital Divide? Online Journal of Communication E Media Technologies, 3(1), 144-162.

Rojas, V., Straubhaar, J., Fuentes-Bautista, M. \& Pinon, J. (May, 2009). Still Divided: Ethnicity, Generation, Cultural Capital and New Technologies. Paper presented at the International Communication Association, New York, United States of America. Retrieved from http://www.allacademic.com/meta/p15201_index.html

Rojas, V., Straubhaar, J., Spence, J., Roychowdhury, D., Okur, O., Piñon, J. \& Fuentes-Bautista, M. (2012). Communities, Cultural Capital, Digital Inclusion: Ten Years of Tracking Techno-Disposition and Techno-Capitial. In J. Straubhaar, J. Spence, Z. Tufekci \& R. Lentz (Eds.), Inequity in the Technopolis: Race, Class, Gender, and The Digital Divide in Austin (pp. 223-264). Texas, United States of America: University of Texas Press.

Straubhaar, J., Tufekci, Z., Spence, J., \& Rojas, V. (2012). Digital Inequity in the Austin Technopolis: An Introduction. In J. Straubhaar, J. Spence, Z. Tufekci, \& R. Lentz (Eds.), Inequity in the Technopolis (pp. 1-32). Texas, United States of America: University of Texas Press.

Strover, S. (2001). Rural Internet Connectivity. Telecommunications Policy, 25(2), 331-347.

United States Census Bureau. (2013). American Factfinder Laredo, Texas. Retrieved from http://factfinder2.census.gov/faces/nav/jsf/pages/community_facts.xhtml\#

Warf, B. (2010). The Digital Divide in the U.S. in the 21st Century. In E. Ferro, Y. Kumar Dwivedi, J. R. Gil-Garcia, \& M. D. Williams (Eds.), Handbook of Research on Overcoming Digtial Divides: Constructing and Equitable and Competitive Information Society (Vol. 1, pp. 112-130). Pennsylvania, United States of America: Information Science Reference.

Warschauer, M. (2004). Physical Resources: Computers and Connectivity. In M. Warschauer (Ed.), Technology and Social Inclusion: Rethinking the Digital Divide (pp. 49-80). Massachusetts, United States of America: мiт Press.

Weinstein, B. L. \& Clower, T. L. (1994). Texas in the Information Age: Economic and Social Impacts of Broadband Telecommunications Infrastructure in Texas. Texas, United States: Center for Economic Development and Research University of North Texas.

Wirth, M. O. (2006). Broadband Convergence: Future Directions and Societal Impacts. JMм: The International Journal on Media Management, 8(1), 19-28. doi:10.1207/ s14241250ijmm0801_4 
María de los Ángeles Flores

Assistant professor at The University of Texas at El Paso. She teaches a variety of courses within the Multimedia Journalism sequence and earned a Ph.D. in journalism from The University of Texas at Austin. Flores has published scholarly work in English and Spanish in several international journals. Currently, she is also Research Associate for the U.s. research group of the Ibero-American Television Fiction Observatory (OBITEL), an international research project on television fiction. Research areas: cross-cultural journalism, journalism trends, political communication, and television studies. Recent publications: Flores, María de los Ángeles, \& Ramírez, Miguel Timoshenkov. (2016). Integración de las herramientas digitales al periodismo multimedia en Tamaulipas: Estudio de caso de la cámara fotográfica, la grabadora de voz digital y la tableta. Revista Contextualizaciones Latinoamericanas, 8(14), 1-16.

\section{Viviana Rojas}

Chilean. Associate Professor of Communication at the University of Texas at San Antonio and obtained her Bachelor in Journalism and Master in Social Communication at the Universidad de Chile. Research areas: international migration, cultural adaptation, and Latinos in the United States. Her most recent publication on the topic of Latinos and media is a book chapter on The Routledge Companion to Latina/o Media titled "Voices from the Borderlands: Young Latinos discuss the impact that culture and identity have on their media consumption" (2016).

Joseph D. Straubhaar

Amon G. Carter Centennial Professor of Communications in the Department of Radio-TVFilm at The University of Texas at Austin. He is the current Director of the Moody College of Communications' Latino and Latin American Studies Program. His primary teaching, research and writing interests: global media, digital media and the digital divide in the U. S. and other countries, Brazilian and Latin American television, media and migration, and global television production and flow. Publications: Rojas, V., Straubhaar, J., Spence, J., Roychowdhury, D., Okur, O., Pinon, J. \& Fuentes-Bautista, M. (2011). Comunidades, Capital Cultural I Inclusão Digital: Acompanhando as Tenděncias Technológicas numa Década. Media e Journalism, 10(2), 15-38. 